\title{
How can the grasslands under rainfall events modify water balance in drought conditions
}

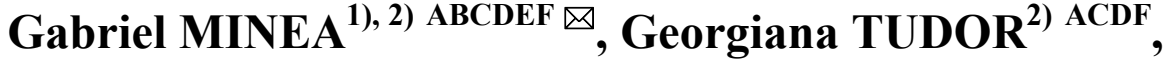 \\ Florentina-Iuliana STAN ${ }^{2)}$ ABCDF , Gabriela IOANA-TOROIMAC ${ }^{\text {3) CDE }}$, \\ Raluca ZAMFIR ${ }^{2)}$ BE
}

\footnotetext{
${ }^{1)}$ Research Institute of the University of Bucharest, University of Bucharest, 36-46 Bd. M. Kogălniceanu, Sector 5, 050107, Bucharest, Romania, e-mail: gabriel.minea@hidro.ro

2) National Institute of Hydrology and Water Management, Bucharest, Romania

${ }^{3)}$ University of Bucharest, Faculty of Geography, Bucharest, Romania
}

For citation: Minea G., Tudor G., Stan F.-I., Ioana-Toroimac G., Zamfir R. 2018. How can the grasslands under rainfall events modify water balance in drought conditions. Journal of Water and Land Development. No. 38 p. $53-$ 65. DOI: 10.2478/jwld-2018-0042.

\begin{abstract}
Taking into account the well-established influence of hillslopes grasslands on runoff processes, the purpose of this study was to investigate how grasslands can affect the water flow pathways on hillslopes, in drought conditions. This study was performed in experimental grassland at plot-scale (e.g., Festuca pratensis), in temperate humid continental climatic conditions of Curvature Subcarpathians, Romania. The rainfall, evapotranspiration, and soil moisture daily data, respectively 208 rainfall and 16 rainfall-runoff events data measured in grassland hills during the growing season (1 April up to 30 September 2015 and 2016) were used. Our results suggest that a runoff event response in extreme drought conditions occurs on grasslands only if precipitation exceeds the threshold of $31 \mathrm{~mm}$ Hortonian overland flow (HOF), while this threshold drops to $17 \mathrm{~mm}$ during moderate droughts and up to $8 \mathrm{~mm}$ for wet conditions. The rainfall events up to $16 \mathrm{~mm}$ proved to be insufficient to completely saturate the soil. Therefore, HOF has only a minor contribution in drought conditions, on grassland and light on bare soil. A complementary and negative effect of grasslands in drought conditions is the water resources suppressing on hillslopes.
\end{abstract}

Key words: grasslands, hydrological drought, plot-scale, rainfall-runoff events, water flow pathways

\section{INTRODUCTION}

Hillslope grasslands are sensitive area to rainfall events. One of the major hydrological challenges that have dominated experimental hydrology for many years concerns the hydrological behaviour of land use and land cover change [CERDA et al. 2018; HOLKO, LEPISTÖ 1997; LATRON et al. 2003; MACLEOD et al. 2013; StANCIU, Zlate-PoDANi 1987]. Over the past decades, increasing drought phenomena [KHEZAZNA et al. 2017], coupled with heavy rainfall events have produced severe extreme hydrological processes (e.g., flash floods) [WARWADE et al. 2018]. The climate changes (decrease in the amount of precipitation and a large increase in air temperature and evapotranspiration) recorded in the $21^{\text {st }}$ century in southern Europe, favoured increased frequency and magnitude of drought episodes and heavy rainstorm events [BĄK, KUBIAK-WÓJCICKA 2017; DAI 2013; VICENTE-SERRANO et al. 2011]. In this context, the hydrological investigate of secondary grasslands can provide a good information about runoff generation processes and water resources. 
In the last few decades, extensive studies have been conducted on identify of runoff variation under changing environment (e.g., land use) at different scale. Few studies regarding runoff generation have been carried out in small catchments (e.g., HOLKO, LEPISTÖ [1997]; LATRON et al. [2003]; BROCCA et al. [2008]; MiţĂ, MĂTREAŢĂ [2016]) and on field or laboratory experimental plots (e.g., DE LIMA, SINGH [2002]; IONIȚĂ et al. [2006]; SCHERRER et al. [2007]; GHOLAMI et al. [2014]; MARZEN et al. [2015]; MINEA et al. [2015]; ABRANTES et al. [2017]; DUAN et al. [2017]). Scientists have examined the hydrological effect of grasslands (e.g., HORTON [1919]; BLIDARU [1965]; FULLEN [1992 1998]; MAETENS et al. [2012]; MACLEOD et al. [2013]; JOYCE et al. [2016]) and suggested that grasslands can regulate both runoff and soil erosion, by trough their potential to intercept rainfall [HORTON 1919; MACLEOD et al. 2007], so called ,biological flood control measure" [JANKOWSKA-HUFLEJT 2006]. DE LIMA and SINGH [2002] observed that local rainfall patterns (uniform, intermediate, advanced, and delayed) are important in determining the peak discharges and hydrograph shapes of the overland flow hydrograph. SCHERRER et al. [2007] conducted a fieldplot study to evaluate the factors influencing the dominant runoff processes. Their findings have revealed that runoff formation can be influenced by a complex interaction of factors (e.g., infiltration rate, soil water storage, and drainage of soil moisture). Runoff ranging from $2 \%$ to more than $90 \%$ of the applied rainfall rate was reported. To investigate the runoff formation along the hillslopes transects, SCHMOCKER-FACKEL et al. [2007] used sprinkling $\left(1 \mathrm{~m}^{2}\right)$ and/or infiltration experiments with a double ring infiltrometer. One of the results of this study, besides maps of the dominant runoff processes, is that runoff formation during intense precipitation is immensely variable and that the interactions involved are complex. In previous work, MiNEA et al. [2015] investigated the role of land use in the dynamics of water resources on a soil-water balance plot following 2014 natural spring rainfalls. Their results showed that the "bare soil" creates heterogeneous conditions for the runoff surface, such as micro-depressions, and thus flow rates have been reduced in comparison to those recorded on the "grassland" soil water balance plot.

However, there is limited information about the relationship between rainfall and grasslands with respect to the water flow pathways on/along grassland hillslopes in drought conditions during natural rainfall. In general, these studies were focused on the runoff process, but failed to identify the hydrological behaviour of grasslands under storm events in dry conditions. The aim of this work was to obtain a greater understanding of the hydrological effect/behaviour on water flow pathways of grasslands in drought conditions (dry periods) under natural rainfall events and to determinate a rainfall event threshold triggering runoff. Due to practical constraints (e.g., catchment heterogeneity), this paper cannot provide an upscaling approach, but we still continue working to find a solution. Therefore, a key issue that will need more attention in the future is transferring data plot to catchment scale [BLÖSCHL, SIVAPALAN 1995]. Our hypothesis is that grassland can generate a regular runoff, but we want to know under drought conditions, which are rainfall event thresholds triggering the runoff. Also, we want to determine grassland effect over successive rainfall events and how can grasslands change water balance. In this respect, our work is focused on rainfall thresholds for runoff process at the plot-scale (soil water balance plots), with the aim of experimentally investigating mechanisms of driving runoff and the role of land use under dry conditions in the Curvature of Subcarpathians, Romania.

\section{EXPERIMENTAL DESIGN AND SAMPLING}

\section{GEOGRAPHICAL FRAMEWORK}

This study is conducted on experimental plotscale situated in the Voinești Experimental Basin VEB, instrumented in the 1960s, at an elevation of $500 \mathrm{~m}$ a.s.l. and it is under administration of National Institute of Hydrology and Water Management. From a geomorphologic viewpoint, the study area is located in Curvature Subcarpathians (hilly region) precisely on the left side of Dâmboviţa River (Fig. 1a), highly exposed to erosion [MIRCEA et al. 2015; ZAHARIA, IOANA-TOROIMAC 2009]. The principal land use of VEB is grassland (67\%) dominated by perennial grass, e.g., Festuca pratensis, Centaurea cyanus. The secondary land use is forest.

The soil is described as a Luvosoil, being composed of $51 \%$ sand, $21 \%$ silt, and $28 \%$ clay [MAFTEI et al. 2002]. According to the Köppen System for climate classification, Curvature Subcarpathians are described by "Dfb" subtype or temperate humid continental climate [PEEL et al. 2007].

Based on observations in 1980-2016, the average evapotranspiration on grassland and bare soil, are 487 $\mathrm{mm} \cdot \mathrm{yr}^{-1}$ and respectively $351 \mathrm{~mm} \cdot \mathrm{yr}^{-1}$. Average multi annual precipitation and average air temperature (1980-2016) are $818 \mathrm{~mm}( \pm 192 \mathrm{~mm})$ and $9.8^{\circ} \mathrm{C}$, respectively. Most rainfall events $(63 \%)$ occur in the warm/growing period (April-September), and the highest number of rainfalls was recorded in summer, from June (12.5\%) to July (12.3\%). July is the wettest month receiving an average of $100 \mathrm{~mm}$ with a standard deviation $(S D)=64 \mathrm{~mm}$, while February is the driest, with $40.1 \mathrm{~mm}, S D=26 \mathrm{~mm}$ precipitation.

Important water resources from rainfall in July the month with maximum pluviometric regime, were concentrated, while a high incidence of short rainfall events (rain shower) was specific for May. Heavy and severe storm events are rare (few episodes per season) and are specific to late summer-early autumn [MINEA et al. 2016]. The highest monthly evapotranspiration measured on bare soil and on grassland occurs in June 


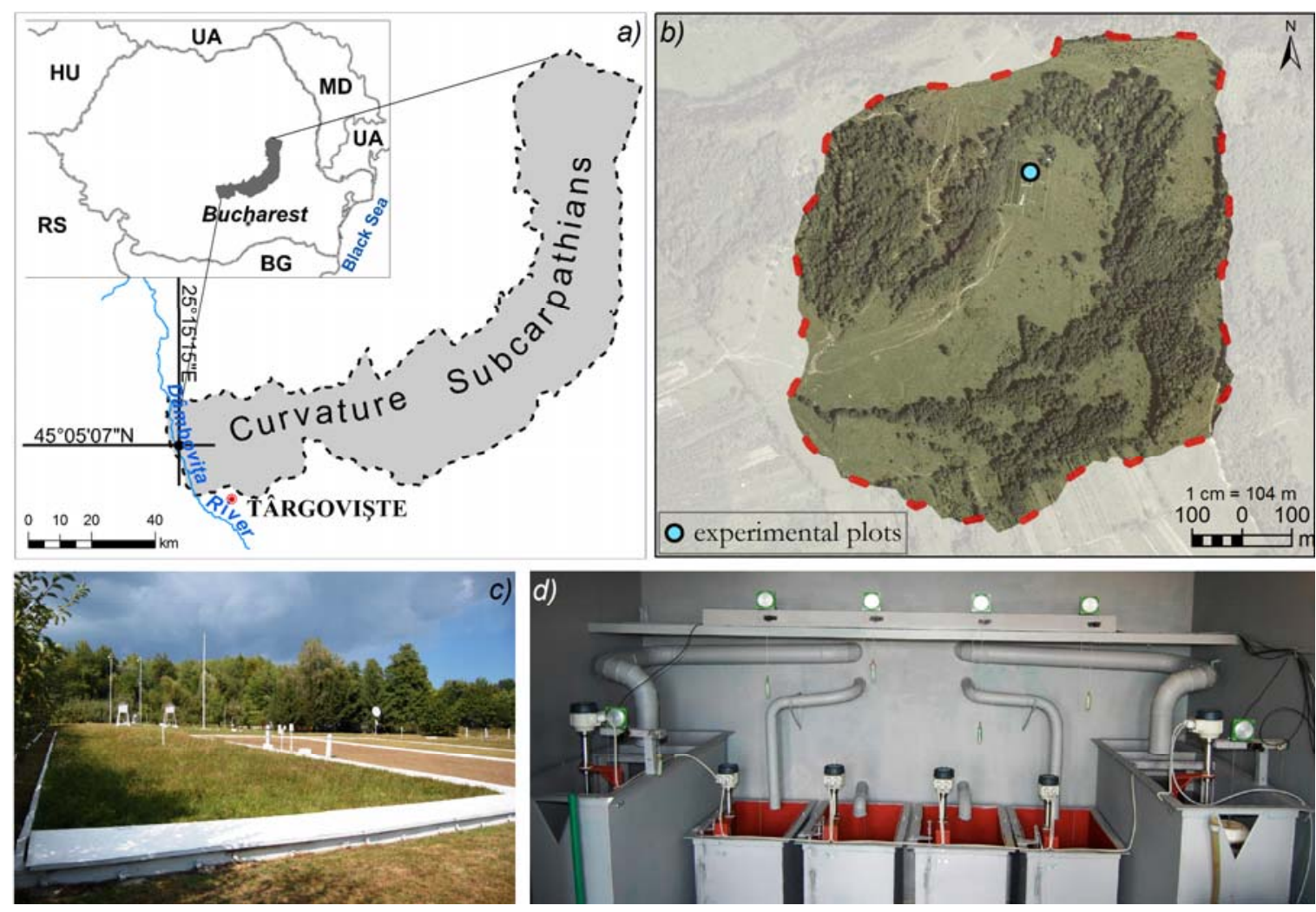

Fig. 1. Site diagram: study area and its location in Curvature Subcarpathians (a), VEB and experimental plot setup (b), "grassland" water soil balance plot (c), and shelter house equipped with calibrated tanks and water level sensor (d); source: own elaboration

(126 mm) or July $(72.4 \mathrm{~mm})$ when the climatic conditions favours the increasing of transpiration for both soil and plants [STAN et al. 2014]. The highest monthly evapotranspiration values correspond to the driest months [OUDA et al. 2015], according to the standardized precipitation evapotranspiration index (SPEI) values [VICENTE-SERRANO et al. 2010]. For VEB, the SPEI-12 months showed that the interval JuneAugust 1980-2016 was characterized by a moderate drought and severe drought until 2011, and by an extreme drought after 2011 [SPEI 2017].

\section{SAMPLING AND FIELD MEASUREMENT}

The equipment has been installed for small experimental plot study in the centre of the VEB (Fig. 1b). The terminology of water flow pathways introduced by SCHERRER et al. [2007] has been used: Hortonian Overland Flow (HOF), SubSurface Flow (SSF) or interflow and Deep Percolation $(D P)$ or Base Flow. The main elements of water balance events investigated in this study are defined in Table 1.

Rainfalls were collected by a pluviometer $(24 \mathrm{~h}$ rainfall amount $-\mathrm{mm}$ ) at the height of $1.5 \mathrm{~m}$ above the ground. The daily accumulated rainfall during 24 hours (07-19-07 h; local time Eastern European Summer Time - ESST), from an IMC - Romanian precipitation storage gauge (reception area $200 \mathrm{~cm}^{2}$, at $1.5 \mathrm{~m}$ above the ground) were investigated. Rainfall events data were collected and recorded by tilting-si-
Table 1. Abbreviations, definitions, and units for the main parameters used to characterize water balance events

\begin{tabular}{|l|l|c|}
\hline $\begin{array}{l}\text { Abbre- } \\
\text { viation }\end{array}$ & Parameter definitions & Unit \\
\hline$E T R$ & $\begin{array}{l}\text { evapotranspiration defined by the amount } \\
\text { of soil water lost to the atmosphere via } \\
\text { evaporation from the ground surface and } \\
\text { from the plant leaves }\end{array}$ & $\mathrm{mm} \mathrm{day}^{-1}$ \\
\hline$P$ & $\begin{array}{l}\text { rainfall depth (meaning the entire amount } \\
\text { of rainfalls during a rainfall event) }\end{array}$ & $\mathrm{mm}$ \\
\hline$I_{\max }$ & maximum intensity of P & $\mathrm{mm} \mathrm{min}^{-1}$ \\
\hline$R$ & $\begin{array}{l}\text { runoff (overland flow; subsurface flow and } \\
\text { base flow) expressed as the maximum } \\
\text { discharge }\left(Q_{\max }\right), \text { volume }(V), \text { or total } \\
\text { depth }\left(R_{t d}\right)\end{array}$ & $\begin{array}{c}Q_{\max }, \mathrm{dm}^{3} \cdot \mathrm{s}^{-1} \\
R_{t d}, \mathrm{~mm}^{3}\end{array}$ \\
\hline$R_{a i}$ & $\begin{array}{l}\text { rainfall average intensity of } P \text { is the } P \\
\text { divided by the time of duration }\end{array}$ & $\mathrm{mm} \mathrm{min}^{-1}$ \\
\hline$S V C$ & volumetric soil moisture content $\left(\theta_{v}\right)$ & $\mathrm{m}^{3} \cdot \mathrm{m}^{-3}$ \\
\hline$R C$ & $\begin{array}{l}\text { runoff coefficient is the ratio between } R \\
\text { and } P\end{array}$ & \\
\hline$E T R_{g}$ & grass evapotranspiration & $\mathrm{mm} \mathrm{day}^{-1}$ \\
\hline$E T R_{b}$ & bare soil evapotranspiration & $\mathrm{mm} \mathrm{day}^{-1}$ \\
\hline
\end{tabular}

Source: own elaboration.

phon gauge (pluviograph), production of the former USSR. MiNEA et al. [2016] described the mechanism and specifics of this pluviograph. For rainfall-runoff analysis, we used only rainfall events defined by precipitation $\geq 0.2 \mathrm{~mm}$ and where there was no precipitation for the following 1 hour.

Soil moisture content - determination of soil water content in grassland is important for water bal- 
ance calculation. Our study uses daily volumetric soil moisture content $\left(\theta_{V}\right)$, indirectly acquired through field measurements (use of electromagnetic signals to measure the permittivity of the soil $(\varepsilon)$ by operating a Delta-T Profile probe, type PR2/6 and its technical operation procedure [DELTA-T 2016]. To provide soil moisture data an epoxy access tube was installed in the grassland of the VEB. Soil moisture content was measured daily around 9:00 ESST, in the upper $1 \mathrm{~m}$ of the soil layer - depths starting at $0.10 \mathrm{~m}$ and up to a $1.00 \mathrm{~m}$ of the soil profile; other measurement depths were $0.20,0.30,0.40$, and $0.60 \mathrm{~m}$.

Evapotranspiration was measured by using a lysimeter, based on the changes of the soil mass. For this study, the evapotranspiration (ETR) was measured by using two large soil tanks (G1 lysimeters) with $1 \mathrm{~m}^{2}$ surface area (circular section) and $1.5 \mathrm{~m}$ depth; one lysimeter measures the ETR of the grass (Photo 1b) and the second lysimeter measures the ETR of the bare soil. The amount of water lost by evapotranspiration is calculated by taking the difference between the weight before and after the precipitation input, daily at 7:00 ESST.

Runoff - for water flow pathways measures (overland flow, subsurface flow, and base flow) a pair soil water balance plots were used. Soil water balance plots (SWBP's) cover an area of $300 \mathrm{~m}^{2}(L=30$ and $l=10 \mathrm{~m})$, with a slope $=13 \%, S$ aspect and $500 \mathrm{~m}$ a.s.l. (Fig. 1c). The land use of the plots falls in the following categories:

1) grasslands - corresponding to secondary perennial grass - SWBPg (Fig. 1c; Photo 1a); the $S W B P g$ were never grazed, but herbage was cut (in July), according to traditional practices; the average height of grasses surrounding the $S W B P g$ was about $40 \mathrm{~cm}$ and a dense superficial network of grass roots-dominated in the top $\sim 20 \mathrm{~cm}$ of the soil;

2) bare soil or "working soil" plot was kept spade under bare soil through manually digging in spring, which consists of tilling with a long-handled shovel to $\sim 20 \mathrm{~cm}$ deep, creating microdepressions that enable rainfall water infiltration and retention of eroded soil, and regular application of the herbicide treatments $(S W B P b)$.

The area of the plots was bordered by an impervious (concrete) wall, a number of collection channels composed of gutters, underground pipes (subsurface flow and base flow), and at their lower part, there were shelters containing calibration water tanks with drainage installation for evacuated water. The concrete walls were dug in at a depth of $1.50 \mathrm{~m}$ and raised above ground by $0.20 \mathrm{~m}$. To stop rainfall collection and its influence on the collecting channel, these were protected by metal caps. Data about subsurface flow were collected from a depth of $0.40 \mathrm{~m}$ (after effective root zone Photo 1c, and sandy clay Bt horizon) and base flow was measured at a depth of $1.30 \mathrm{~m}$ [BLIDARU 1965], using hydrometrical devices (e.g., water tank; water level sensors: OTT SE 200 model; see Fig. 1d) and the volumetric method $V=$ $f(H)$, previously described by MINEA and MOROŞANU [2016]. Rating curve $Q=f(H)$ were used to determine overland flow discharges.

\section{DATA AND METHODS}

Data in our study includes of daily depth rainfall, evapotranspiration depth, volumes of soil moisture content, and runoff event elements (depths, discharges and volumes), and rainfall event elements (depths, duration, intensities) respectively from 1 April up to 30 September 2015 and 2016 (two consecutive dry seasons).

The data have been subject to individual quality control procedures of the Institutul Naţional de Hidrologie şi Gospodărire a Apelor - National Institute of Hydrology and Water Management (NIHWM). Unfortunately, for technical reasons (e.g., water infiltration through a concrete wall, land use management), we were unable to use the subsurface flow and base flow database over a larger period.

Missing data were identified in the time series of rainfall events and soil moisture content. These errors were due to incorrect processing and consisted of the temporal continuity of a rainfall event, between two sequences (rainfalls with 1-hour break). After data check operation, the series (rainfall data) were divided into events. For soil moisture data in rainy days ( 1 or 2 days periods) with no measurements (missing data value) or with an ambiguous quality of records, we used an interpolation method following the protocol described by HoTTENSTEIN et al. [2015]. According to previous studies, the soil moisture data were interpolated by averaging the soil moisture values from the first measured values on dates before and after missing data.
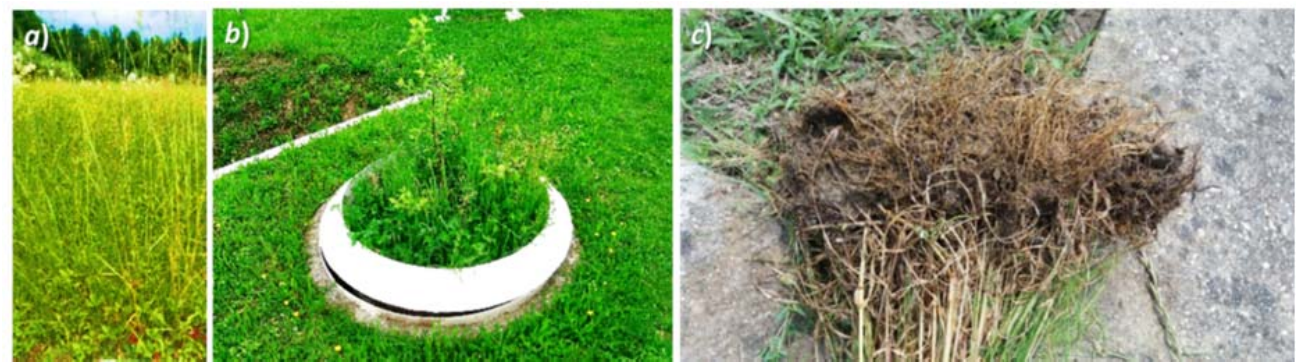

Photo. 1. Grass from the soil water soil balance plot (a) lysimeter (b) and root system (c) in VEB; phot. G. Minea, F.-I. Stan, G. Niţă 


\section{ANALYSIS METHODS}

From the point of view of field experiment method, these are often used to measure in situ daily rainfall, soil moisture contents, and evapotranspiration data, rainfall-runoff events (overland flow, subsurface flow, and base flow or deep percolation). Supplementary details about the field and devices are given by STAN et al. [2014], MinEA and MoRoşANU [2016].

The methodological approach chosen for this study is a mixed design based on water balance equation. To detect the hydrological influence of grasslands on drought conditions, the periods and drought intensity were identified. An indicator used to identify long-term drought periods (e.g., minimum 1 month) was SPEI.

For soil water statute (deficit or excess), an indicator called daily soil water balance $(D S W B)$ was chosen. The $D S W B$ is based on the water balance equation and takes into account: rainfall, evapotranspiration, and soil water reserve. All the water input are expressed in $\mathrm{mm}$. According to RODRíGUEZ-BLANCO et al. [2012], firstly, the rainfall minus outflow ( $P$ and $E T R$ ) was calculated to represent the soil water available for each day (Eq. 1) and secondly, the soil water balance for each day (mm) was calculated to tell on whether there is a surplus or a deficit (Eq. 2).

$$
P-E T R_{g}= \pm \Delta S
$$

Where: $P=$ amount of rainfall $(\mathrm{mm}) ; E T R_{g}=$ amount of grass evapotranspiration (mm); $\Delta S=$ amount of soil storage change, plus $=$ increase, minus $=$ decrease (mm).

$$
D S W B=\Delta S_{\mathrm{PSD}}-\Delta S_{\mathrm{PVD}}
$$

Where: $D S W B=$ daily amount of soil water balance; $\Delta S_{\mathrm{PSD}}=$ present-day amount of soil storage; $\Delta S_{\mathrm{PVD}}=$ previous-day amount of soil storage.

$D S W B$ allowed quantitative estimation of hydrological soil deficit and identification of drought periods (intensity/asperity). Further, $D S W B$ was classified by using percentiles, and reclassified as follows: extreme drought, moderate and wet. The severity degree of rainfall-runoff events was studied when compared to drought periods.

\section{STATISTICAL ANALYSIS}

Rainfall, soil moisture content, and runoff elements for water flow pathways (e.g., volumes, discharge), Standard deviation and coefficient of variation were condensed in tables and represented in graphical form including discharge, amounts, comparison of runoff volumes, runoff coefficients $(R C)$. Correlations and other types of analysis using the descriptive statistics (e.g., location and variability: percentiles, skewness and kurtosis as numerical measures of the shape of data) were calculated.

In order to understand how grasslands can affect the water flow pathways at microscale in drought conditions, 208 rainfall events, and 16 natural experiments (rainfall-runoff) were studied. Hydrological grasslands effects were assessed based on soil water balance elements and $R C$. Depending on rainfall event size, we identified a pluviometric threshold of hillslope runoff generation.

All analyses of the water balance data were conducted by using OriginPro 9.3 software [OriginLab 2016].

\section{RESULTS AND DISCUSSION}

For the period of 2015-2016, rainfall events, rainy days, ETR and drought periods with different intensity/rates, respectively rainfall-runoff events were registered. Runoff events were individualized both by land use, water flow pathways, and through $R C$. To investigate the relationship between grassland and rainfall (daily and events data), we first used descriptive statistics. Tables 2 and 3 reflect the water resources variability of this study.

\section{GROWING SEASON 2015}

The data of the rainfall events revealed nonperiodic variability of the number of days with precipitation in alternation with drought periods (meteorological droughts), and few extreme rainfall (highest rainfall events).

We found 59 rainless days $(32.2 \%$ during the analyzed period) with the longest dry periods: August, July, and September with 13, 12 and 11 consecutive days without any rain. The most severe dry periods during the drought were from the second half period of July to September (exceptional in terms of its duration and intensity), when corresponding soil moisture content deficits increased. On a monthly scale, the maximum number of rainy days $(35.5 \%)$ were recorded in September and June (155.3 and $103.9 \mathrm{~mm}$ ) and the minimum in July $(11.1 \mathrm{~mm})$. The lowest daily rainfall was recorded in the lower quartile (the $25^{\text {th }}$ percentile mark) (minimum $0.2 \mathrm{~mm}$ in April and 0.25 mm July), while an important increase was noticed by the third quartile (maximum $23 \mathrm{~mm}$ in September followed by $14.7 \mathrm{~mm}$ in June) (Tab. $2 \mathrm{a}$ ). In September, a wet period with 7 rainfall days $(128.3 \mathrm{~mm})$ produced important runoff on hillslopes and flash floods. The ETRg, between April and September 2015 was $567 \mathrm{~mm}$, while the evapotranspiration on bare soil was only $246.3 \mathrm{~mm}$. The maximum daily evapotranspiration for the bare soil was measured in June (7 $\mathrm{mm} \cdot \mathrm{day}^{-1}$ on 06 June 2015) and for the grassland in July $\left(9 \mathrm{~mm} \cdot \mathrm{day}^{-1}\right.$ on 08 July 2015). Daily values of evapotranspiration vary more significantly for the bare soil $(C v=0.8-1.1)$, than for the grass $(C v=0.4$ 0.8 ), due to the fact that the bare soil lost supplementary water, more quickly the covered soil retained the water for a longer period of time. The monthly evapotranspiration on grassland values started to increase from $65 \mathrm{~mm} \cdot \mathrm{month}^{-1}$ (in April) to $121 \mathrm{~mm} \cdot \mathrm{month}^{-1}$ 


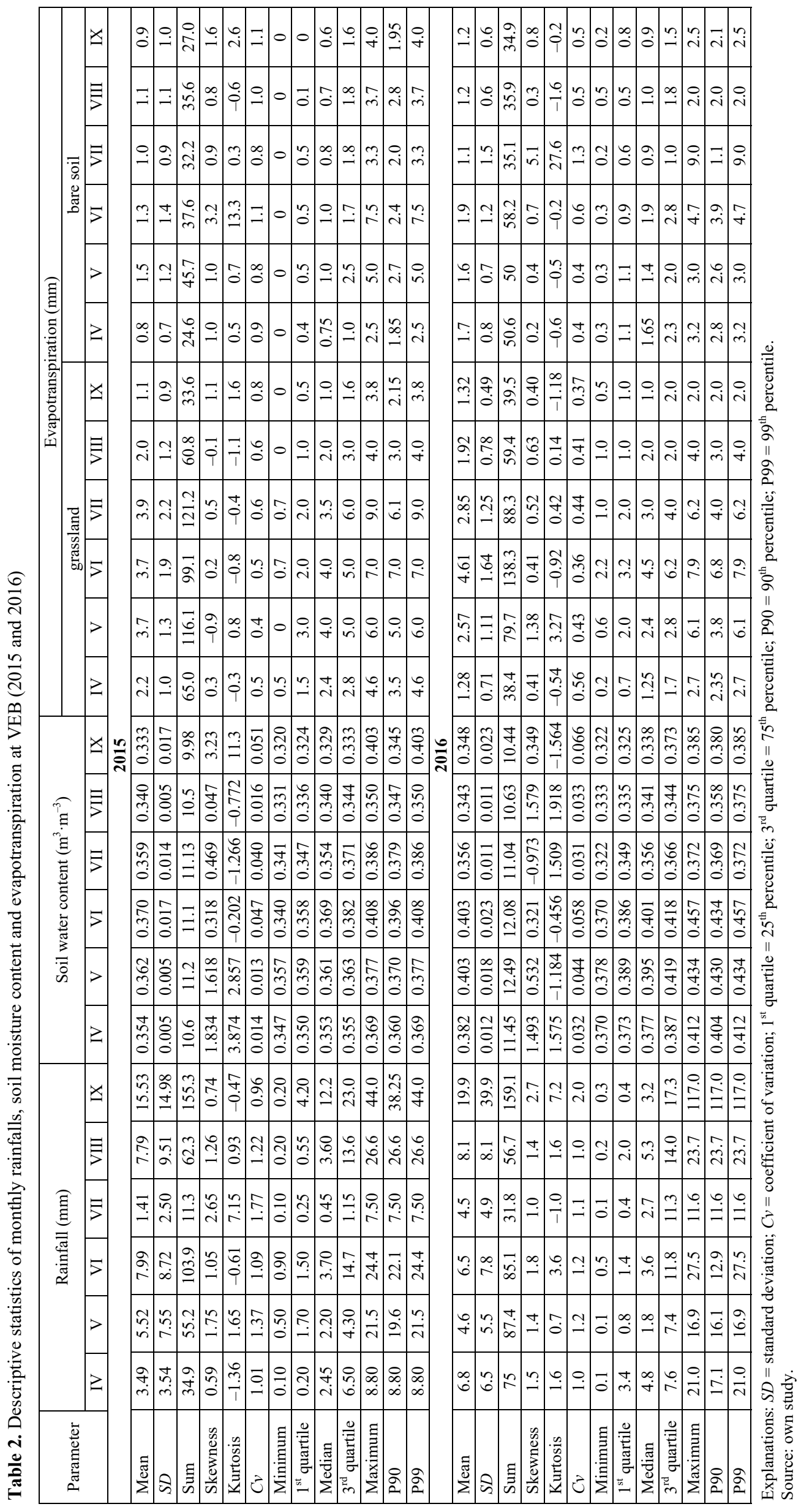


Table 3. Characteristics of the main rainfall events during the growing season (2015 and 2016)

\begin{tabular}{|c|c|c|c|c|c|c|}
\hline \multirow{2}{*}{$\begin{array}{l}\text { No. } \\
\text { events }\end{array}$} & \multirow{2}{*}{\multicolumn{2}{|c|}{$\begin{array}{c}\text { Time } \\
\text { (day.month.year } \\
\text { hour: minute) }\end{array}$}} & \multirow{3}{*}{$\begin{array}{c}\begin{array}{c}\text { Dura- } \\
\text { tion } \\
(\mathrm{min})\end{array} \\
40\end{array}$} & \multirow{3}{*}{$\begin{array}{c}\begin{array}{c}D \\
(\mathrm{~mm})\end{array} \\
17.8\end{array}$} & $I_{\text {avg }}$ & $I_{\max }$ \\
\hline & & & & & \multicolumn{2}{|c|}{$\mathrm{mm} \cdot \mathrm{min}^{-1}$} \\
\hline 1 & $\begin{array}{c}5.06 .2015 \\
19: 20\end{array}$ & $\begin{array}{c}5.06 .2015 \\
20: 00\end{array}$ & & & 0.445 & 0.900 \\
\hline 2 & $\begin{array}{c}25.05 .2015 \\
18: 00\end{array}$ & $\begin{array}{c}25.05 .2015 \\
20: 40\end{array}$ & 160 & 20.8 & 0.130 & 1.040 \\
\hline 3 & $\begin{array}{c}17.06 .2015 \\
2: 00\end{array}$ & $\begin{array}{c}17.06 .2015 \\
5: 10\end{array}$ & 190 & 24.5 & 0.129 & 0.140 \\
\hline 4 & $\begin{array}{c}27.06 .2015 \\
7: 20\end{array}$ & $\begin{array}{c}27.06 .2015 \\
21: 20\end{array}$ & 840 & 24.0 & 0.029 & 0.220 \\
\hline 5 & $\begin{array}{c}31.07 .2015 \\
22: 00\end{array}$ & $\begin{array}{c}1.08 .2015 \\
1: 40\end{array}$ & 220 & 31.0 & 0.141 & 0.587 \\
\hline 6 & $\begin{array}{c}28.09 .2015 \\
00: 30\end{array}$ & $\begin{array}{c}28.09 .2015 \\
12: 00\end{array}$ & 690 & 27.9 & 0.040 & 0.100 \\
\hline 7 & $\begin{array}{c}28.09 .2015 \\
13: 10\end{array}$ & $\begin{array}{c}29.09 .2015 \\
11: 00\end{array}$ & 1310 & 35.9 & 0.027 & 0.100 \\
\hline 8 & $\begin{array}{c}1.06 .2016 \\
1: 20\end{array}$ & $\begin{array}{c}1.06 .2016 \\
7: 00\end{array}$ & 340 & 29.8 & 0.088 & 0.260 \\
\hline 9 & $\begin{array}{c}21.04 .2016 \\
6: 00\end{array}$ & $\begin{array}{c}21.04 .2016 \\
11: 00\end{array}$ & 300 & 35.3 & 0.118 & 0.700 \\
\hline 10 & $\begin{array}{c}13.05 .2016 \\
2: 50\end{array}$ & $\begin{array}{c}13.05 .2016 \\
6: 20\end{array}$ & 210 & 16.4 & 0.078 & 0.540 \\
\hline 11 & $\begin{array}{c}16.07 .2016 \\
02: 30\end{array}$ & $\begin{array}{c}16.07 .2016 \\
03: 40\end{array}$ & 70 & 10.2 & 0.146 & 0.700 \\
\hline 12 & $\begin{array}{c}19.09 .2016 \\
8: 20\end{array}$ & $\begin{array}{c}19.09 .2016 \\
11: 10\end{array}$ & 170 & 47.5 & 0.259 & 0.513 \\
\hline 13 & $\begin{array}{c}20.09 .2016 \\
0: 00\end{array}$ & $\begin{array}{c}20.09 .2016 \\
13: 40\end{array}$ & 820 & $78.0 *$ & 0.100 & 0.420 \\
\hline 14 & $\begin{array}{c}25.09 .2016 \\
14: 40\end{array}$ & $\begin{array}{c}25.09 .2016 \\
15: 50\end{array}$ & 70 & 16.0 & 0.229 & 0.400 \\
\hline
\end{tabular}

Explanations: $D=$ depth; $I_{\text {avg }}=$ average rainfall intensity; $I_{\max }=$ maximum intensity rainfall; * = this rainfall event had two peaks. Source: own study.

(in July), whereas the bare soil evapotranspiration varied from $24.6 \mathrm{~mm} \cdot \mathrm{month}^{-1}$ (in April) to 45 $\mathrm{mm} \cdot \mathrm{month}^{-1}$ (in May); both parameters were decreasing until September (less than $34 \mathrm{~mm} \cdot \mathrm{month}^{-1}$ ) due to the lower air temperature and higher air humidity (Tab. 2).

During growing season, 91 rainfall events characterized by insignificant depths (e.g., for the $95^{\text {th }}$ and $75^{\text {th }}$ percentiles where $24.3 \mathrm{~mm}$ and $5.75 \mathrm{~mm}$, respectively time $667.5 \mathrm{~min}$ for the $95^{\text {th }}$ and $170 \mathrm{~min}$ at $75^{\text {th }}$ percentiles) were recorded. Rainfall events ranged in depth from $0.20-35.9 \mathrm{~mm}$ over $10-1310 \mathrm{~min}$ with low average intensity, $0.004-0.445 \mathrm{~mm} \cdot \mathrm{min}^{-1}$. Exceptional rainfall events occurred on 28-29.09.2015, with a depth about $63.8 \mathrm{~mm}(27.9 \mathrm{~mm}$ over $690 \mathrm{~min}$ on 28.09 and $35.9 \mathrm{~mm}$ over $1310 \mathrm{~min}$ on 29.09); 1.04 , by a depth of $31 \mathrm{~mm}$ over $220 \mathrm{~min} ; 25.05$ by a depth de $20.8 \mathrm{~mm}$ over $160 \mathrm{~min} ; 6.06$, by a depth $17.8 \mathrm{~mm}$ over $40 \mathrm{~min}$. In Table 3 , the main elements of rainfall events from the study, which generated runoff in growing season 2015/2016, are centralized.

\section{GROWING SEASON 2016}

Time series of daily rainfalls showed drought periods (meteorological droughts), rainfall days and few extreme rainfalls (highest rainfall events).

We found 118 rainless days $(64.5 \%$ during analysed period) with 3 long driest periods: i) beginning of April with 10 days; ii) the last two decades of July and the beginning of August (24 days); iii) the last decade of August and the first two decades of September (31 days). The most severe dry periods during the drought were August to September (exceptional in terms of its duration and intensity) and corresponding to highest deficits of soil moisture content.

Generally, the number of rainy days $(35.5 \%)$ was highest in May (19 days; $87.4 \mathrm{~mm}$ ) and lowest in July (7 days; $31.8 \mathrm{~mm}$ ) - August (7 days; $56.7 \mathrm{~mm}$ ). The lowest daily rainfall was emphasized by lowest quartile (minimum $0.4 \mathrm{~mm}$ in July and September) and by an important increase to the third quartile (maximum $17.3 \mathrm{~mm}$ in September) - Table 2. Statistically (location and variability), the lack of symmetry was visible by skewness and kurtosis values despite data constraints available for short periods (Tab. 2). The number of rain-days with soil moisture content excess was greatest in May (19 rain-days with 6 rain-days consecutive). On 20-21 September 2016, an extreme rainstorm led to a significant runoff on the hillslopes and flash floods (e.g., on 20 September of $117 \mathrm{~mm}$, of which $81.8 \mathrm{~mm}$ fell between 00:00 and 13:40 ESST). ETR, between April and September 2016, was approximately $200 \mathrm{~mm}$ higher on grass soil than from the bare soil, the greatest difference being registered between May and August (Tab. 2). Daily values did not vary significantly from one day to another $(E T R \mathrm{~s}$, $C v=0.6 ; E T R g, C v=0.4)$ - Table 2. The maximum possible daily value attained during the growing period for grassland was $7.8 \mathrm{~mm} \cdot$ day $^{-1}$ (22.06.2016), while for bare soil it was $4.7 \mathrm{~mm} \cdot \mathrm{day}^{-1}(8.06 .2016)$. These differences could be due to the water loss by evaporation. The grassland evapotranspiration started to increase from April to July, from $50 \mathrm{~mm} \cdot \mathrm{month}^{-1}$ to $130 \mathrm{~mm} \cdot \mathrm{month}^{-1}$, and then it decreased until attending $40 \mathrm{~mm} \cdot \mathrm{month}^{-1}$ in September, in accordance with the air temperature variation and humidity annual distribution.

Regarding rainfall events, during the growing season, 117 rainfall cases occurred. Compared to 2015 , these events were characterised by insignificant depths (e.g., for the $95^{\text {th }}$ and $75^{\text {th }}$ percentiles where 16 $\mathrm{mm}$ and $3.53 \mathrm{~mm}$, respectively; lifetime $295 \mathrm{~min}$ for the $95^{\text {th }}$ and $80 \mathrm{~min}$ for $75^{\text {th }}$ percentiles). Rainfall events ranged in depth from 0.2 to $81.8 \mathrm{~mm}$ over 10 910 min with low maximum intensity, and average intensity $0.004-0.430 \mathrm{~mm} \cdot \mathrm{min}^{-1}$. Exceptional rainfall events occurred similarly to 2015, in September.

Thus, persistent heavy rains from 19-20.09.2016 recorded the most considerable depths of 125.8 (81.8 $\mathrm{mm}$ over $820 \mathrm{~min}$ on 20.09). This rainfall had two peaks: first time 00:00-04:30, depth $=42.8 \mathrm{~mm}$; second time: $05: 00-13: 40$, depth $=39 \mathrm{~mm}) ; 44 \mathrm{~mm}$ over $170 \mathrm{~min}$ on 19.09); 20.04 with a layer of $35.3 \mathrm{~mm}$ over $300 \mathrm{~min}$; 1.06 with a depth $29.8 \mathrm{~mm}$ over 340 min; 17.08 with a layer of $22.48 \mathrm{~mm}$ over $70 \mathrm{~min}$ (Tab. 3).

The effect of soil water storage due to daily rainfall. Soil moisture content - higher precipitation 

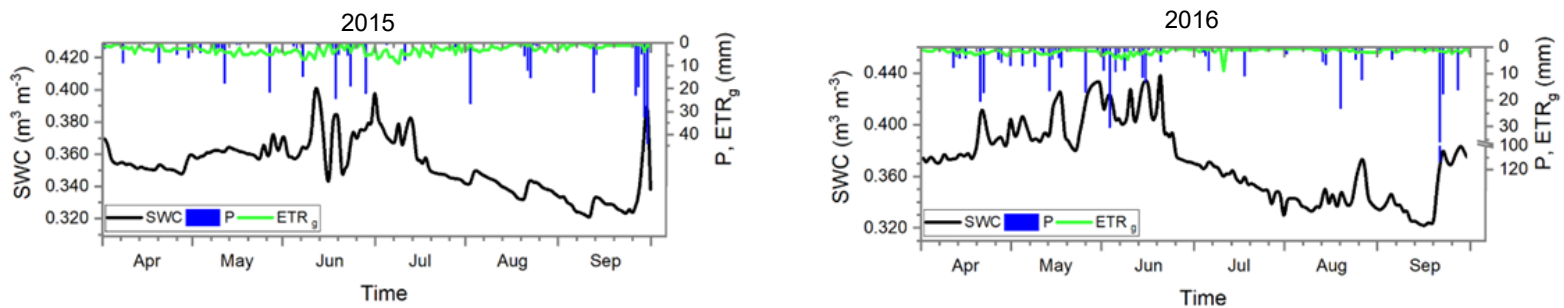

Fig. 2. Daily values of soil water content $(S W C)$, rainfall $(P)$ and grass evapotranspiration $(E T R g)$ during the growing season (from April 1 up to September 30) of 2015 and 2016 in VEB; source: own study

Table 4. Runoff characteristics for all rainfall-runoff events on SWBP's during growing seasons 2015-2016

\begin{tabular}{|c|c|c|c|c|c|c|c|c|c|c|c|}
\hline \multirow{2}{*}{$\begin{array}{c}\text { Number and } \\
\text { data events }\end{array}$} & \multirow{2}{*}{$\begin{array}{c}P \\
(\mathrm{~mm})\end{array}$} & $\begin{array}{c}\theta_{v} \\
\left(\mathrm{~m}^{3} \cdot \mathrm{m}^{-3}\right)\end{array}$ & \multicolumn{3}{|c|}{ Runoff volume $\left(\mathrm{dm}^{3}\right)$ in water flow pathways } & \multicolumn{2}{c|}{$R C^{*}$} \\
\hline 1 & 25.05 .2015 & 20.8 & 0.358 & 10 & 215.2 & 3.75 & & & 515 & 0.00 & 0.12 \\
\hline 2 & 06.06 .2015 & 17.8 & 0.360 & 6 & 242 & & & 0.5 & 670 & 0.00 & 0.17 \\
\hline 3 & 17.06 .2015 & 24.5 & 0.355 & 2.5 & 7.5 & & & & 171 & 0.00 & 0.02 \\
\hline 4 & 27.06 .2015 & 24.0 & 0.374 & 1.5 & 3.5 & 107.7 & & 204.5 & 3044 & 0.00 & 0.42 \\
\hline 5 & 31.07 .2015 & 31.0 & 0.341 & 14.8 & 1994 & 17 & 2.5 & 16.25 & 85 & 0.00 & 0.22 \\
\hline 6 & 21.04 .2016 & 17.3 & 0.352 & & & 3 & & 67.5 & 1253 & 0.00 & 0.12 \\
\hline 7 & 13.05 .2016 & 16.7 & 0.387 & 4.43 & 16.2 & 31 & & & 191 & 0.00 & 0.04 \\
\hline 8 & 16.05 .2016 & 7.6 & 0.424 & 13.2 & 1.97 & 28.5 & & & 203 & 0.00 & 0.09 \\
\hline 9 & 24.05 .2016 & 17.0 & 0.394 & 2.95 & & 5 & & 4.8 & 14,3 & 0.00 & 0.00 \\
\hline 10 & 30.05 .2016 & 8.8 & 0.405 & 8.36 & 132 & & & & & 0.00 & 0.05 \\
\hline 11 & 02.06 .2016 & 30.4 & 0.420 & 1770 & 1738 & & & & & 0.01 & 0.19 \\
\hline 12 & 17.07 .2016 & 11.0 & 0.354 & 1.48 & & & & & 40 & 0.00 & 0.01 \\
\hline 13 & 19.09 .2016 & 47.5 & 0.322 & 7.38 & 2452 & 5.5 & 35 & & 24,2 & 0.00 & 0.18 \\
\hline 14 & 20.09 .2016 & 42.0 & 0.353 & 3.94 & 7310 & 100 & 37.7 & & 225,3 & 0.00 & 0.60 \\
\hline 15 & 20.09 .2016 & 36.0 & 0.384 & 261 & 3524 & 475 & 342 & 1682 & 2958 & 0.01 & 0.63 \\
\hline 16 & 25.09 .2016 & 16.8 & 0.368 & & & & 7.25 & 27.8 & 801 & 0.00 & 0.16 \\
\hline
\end{tabular}

Explanations: $P=$ rainfall event depth; $\theta_{v}=$ moisture soil content-antecedent condition; $H O F=$ Hortonian overland flow, $S S F=$ subsurface flow, and $D P=$ deep percolation (base flow); $R C=$ runoff coefficients; $S W B P$ with subscript land use = soil water balance plot, and $\mathrm{g}^{*}=$ grassland, $\mathrm{s}_{*}=$ soil; an empty cell is an event without flow.

Source: own study.

period juxtaposed with lower evapotranspiration in April-June was higher in the first part of the studied period (Fig. 2). Over the favourable pluviometric period (21.04-19.06.2016), a daily maximum soil moisture content occurred on 19.06.2016 reaching a water content of $0.457 \mathrm{~m}^{3} \cdot \mathrm{m}^{-3}$. The wettest conditions occurred on $21.04\left(0.412 \mathrm{~m}^{3} \cdot \mathrm{m}^{-3}\right)$ and $30.05(0.434$ $\left.\mathrm{m}^{3} \cdot \mathrm{m}^{-3}\right)$. After the longest dry period, the highest rainfall event on 20-21.09 led to an important amount of infiltration and soil moisture content increase $(0.042$ $\mathrm{m}^{3} \cdot \mathrm{m}^{-3}$ ) of $384 \mathrm{~mm}$. Drought periods (including light precipitation) and higher evapotranspiration in summer months triggered a strong deficit in soil moisture. The pronounced long driest conditions occurred on 24.06 up to 18.09 (maximum $0.322 \mathrm{~m}^{3} \cdot \mathrm{m}^{-3}$ ) and also on 30.07 up to 15.092016 (Fig. 2).

\section{WATER FLOW PATHWAYS AT THE PLOT-SCALE}

Using $D S W B$, we quantified the hydrological soil deficit and identified drought intensity. In order to identify the triggering and dominant runoff processes at the plot-scales in hydrological drought conditions (extreme, moderate and wet) we studied 208 rainfalls and a 16 rainfall-runoff events that occurred in growing season, during drought episodes of 2015 and 2016.
Hydrological characteristics of the analysed rainfall-runoff events are presented in Table 4, while here, it is worth mentioning that only 16 natural rainfall events $(7.7 \%)$ had the capacity to generate a hydrological response (13 rainfall events produced Hortonian overland flow - HOF, 11 rainfall events produced subsurface flow - SSF and 14 produced deep percolation $-D P$ ), at least on one of the water flow pathways.

Extreme drought conditions. Two rainfall-runoff events in extreme drought conditions $\left(\theta_{v}=\right.$ $0.322 \mathrm{~m}^{3} \cdot \mathrm{m}^{-3}$ and $\theta_{v}=0.341 \mathrm{~m}^{3} \cdot \mathrm{m}^{-3}$ ), generated by 2 extreme heavy rainfall events $47.5 \mathrm{~mm}$

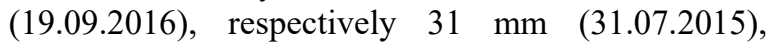
showed similar conditions of water flow pathways. In the case of $H O F$, the largest amounts of runoff on bare soil were $17.2 \%$ for the first event and $21.4 \%$ for the second one. Most of the runoff $(82.4 \%$, respectively $78 \%)$ was distributed in the porous soil $\left(\theta_{v}=\right.$ $\left.0.362 \mathrm{~m}^{3} \cdot \mathrm{m}^{-3}, \theta_{v}=0.350 \mathrm{~m}^{3} \cdot \mathrm{m}^{-3}\right)$, the infiltrating water passing to the groundwater or to the storage. The grassland effect associated with extremely dry conditions has shown that runoff minimizes all water flow pathways and close quantitative values (HOF $0.16 \%$; SSF $0.18 \%$; DP $0.17 \%$, for second events), otherwise $R C$ was expressive in this case $(0.01)$. The rainfall events with $16.8 \mathrm{~mm}$ depth did not produce a hydrological response to drought conditions. 

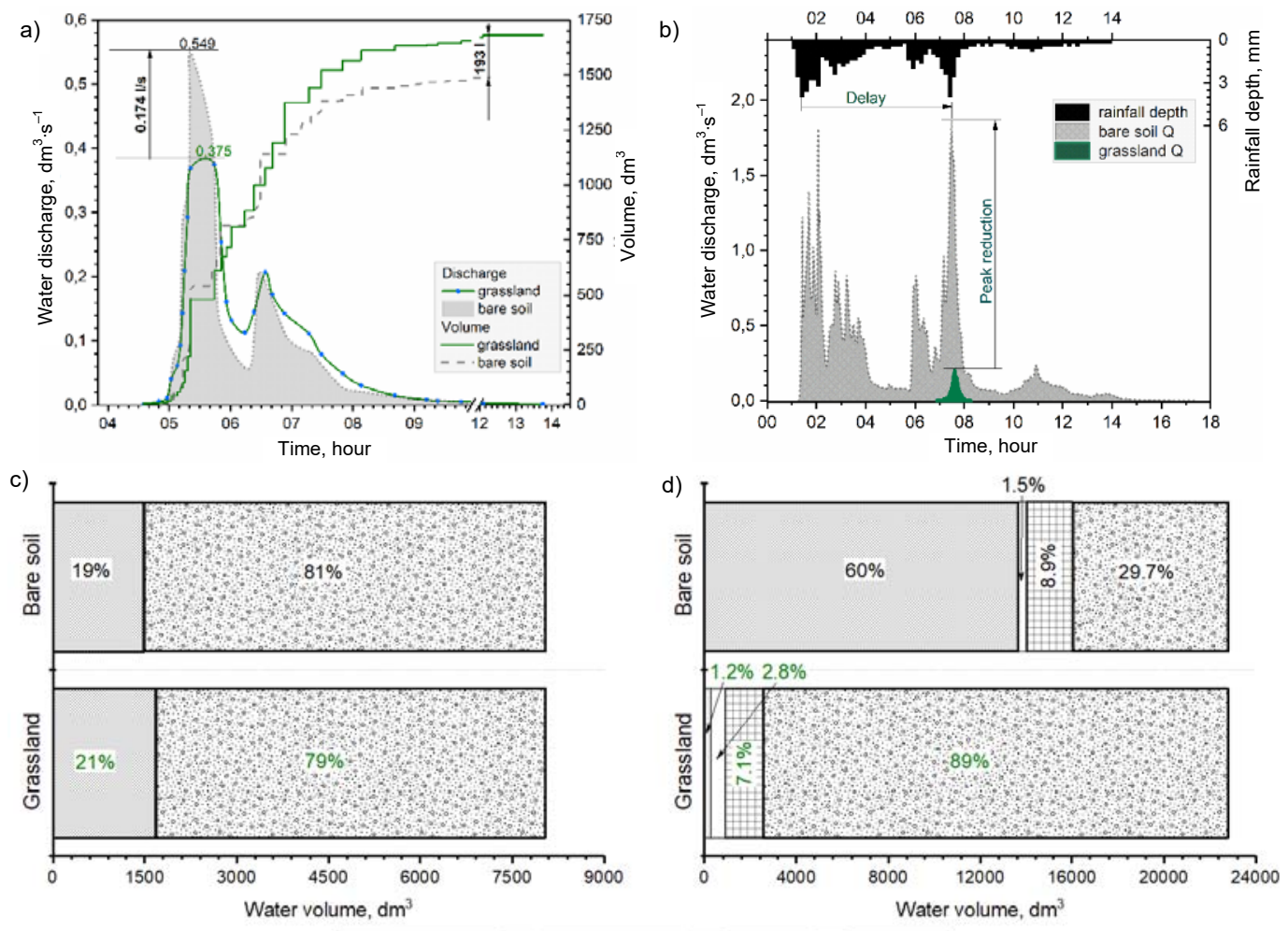

Fig. 3. Rainfall events hydrographs of discharge and volume (lag time, peak discharge, mass curve) for: a) Hortonian overland flow $(H O F), 2.06 .2016$, b) $H O F, 20.09 .2016$, c) water volume pathways on soil water balance plots $(S W B P)$, 2.06.2016, d) $S W B P, 20.09 .2016$; source: own study

Moderate drought conditions $\left(\theta_{v}=0.345 \mathrm{~m}^{3} \cdot \mathrm{m}^{-3}\right.$ $\left.\ldots \theta_{v}=0.368 \mathrm{~m}^{3} \cdot \mathrm{m}^{-3}\right)$. The rainfall-runoff events of this drought category have revealed the role of rainfalls size and intensity and of land use. Runoff events for $20.8 \mathrm{~mm}$ rainfall were characterized by unimportant values of runoff coefficients $(0.12$ for bare soil and 0.001 for grass cover) e.g., on $S W B P g$, in the case of $H O F$ and $D P$ these did not generate runoff, while the $S S F$ volume was $3.75 \mathrm{dm}^{3}$; a similar effect was observed on SWBPS - high water storage; and permeability of topsoil for $S S F$. Main runoff features were: the decrease of $H O F$ on $S W B P g(R C=0)$ and even the absence of runoff comparative on $\operatorname{SWBPS}(R C=0.12)$.

A second rainfall-runoff event consisted of a heavy rainfall with $17.8 \mathrm{~mm}$ depth $\left(40 \mathrm{~min} ; R_{a i}=\right.$ $0.445 \mathrm{~mm} \cdot \mathrm{min}^{-1}$ ) and revealed the same runoff conditions, highlighted by runoff processes occurrence for $H O F$ (Fig. 3). This highly torrential rainfall $\left(I_{\max }=\right.$ $0.900 \mathrm{~mm} \cdot \mathrm{min}^{-1}$ ), but weaker start than above, highlights the influences over the conditioning of surface water formation and rain intensity. However, on $S W B P S$ there was a high capacity of soil water retention (low volume and discharge of $H O F$, for duration of 40 minutes) compared to SWBPS (high volume and discharge of $H O F$, for a duration 60 minutes), $R C=$ 0.17 to $S W B P g, R C=0.17$ to $S W B P s$.

Light drought (wet) conditions $\left(\theta_{v} \geq 0.370\right.$ $\mathrm{m}^{3} \cdot \mathrm{m}^{-3}$ ). In September (19-20.09.2016), high runoff was comprised of two consecutive heavy rainstorms events with rainfall reaching $125.5 \mathrm{~mm}$. These rainfalls caused three successive major runoff events
(20.09.2016), and the first peak $(47.5 \mathrm{~mm})$ of the rain were considered responsible for the increase in the soil-surface moisture content and for the runoff generation. Subsequently, a heavy rainfall on 20.09.2016 (42 mm, $36 \mathrm{~mm}$ and cumulated $78 \mathrm{~mm}$; see Tab. 3) produced massive runoff, especially for the second runoff events, with double peak hydrographs for bare soil (Fig. 3b). In terms of water flow pathways, we observed a preferential flow for DP (which was identified as the dominant process on the bare soil) and SSF (especially on bare soil, with negligible volumes) (Fig. 3d).

The present study shows that, in drought conditions, values of rainfall depth events have varied suggestively (Tab. 2), secondary grasslands have modified the soil water balance and attenuated $H O F$ peaks, and both land use patterns retain much of the rainfall stored in the soil. In this context, the following questions are to be asked:

1) how can secondary grasslands modify soil water balance $\left(1^{\text {st }}\right)$ ?

2) can the secondary grasslands attenuate $H O F$ over successive rainfall events $\left(2^{\text {nd }}\right)$ ?

1. We appreciate that in drought conditions, in particular in extreme conditions, rainfall event characteristics (e.g., rainfall intensity), in relation to grassland (e.g. vegetation phenology, root-depth, decayed and live plant roots), can play a decisive role in water balance. Also, the storage capacity of the soil remains a function of the porosity, which can control shortterm storm and storage capacity. 


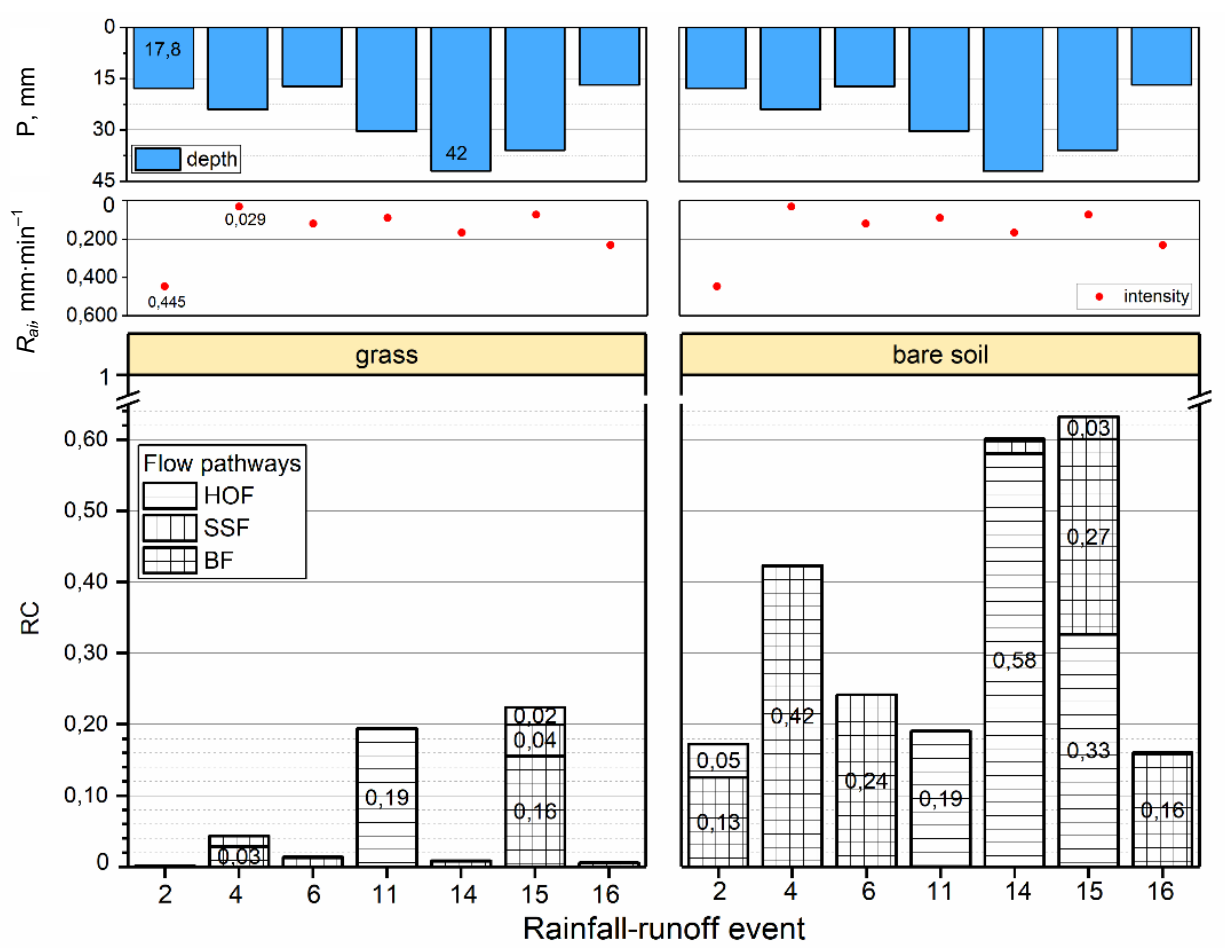

Fig. 4. Rainfall depth $(P)$ and average intensity of rainfall event $\left(R_{a i}\right)$, and associated runoff coefficients $(R C)$, $\mathrm{HOF}=$ Hortonian overland flow, SSF subsurface flow, $\mathrm{BF}=$ base flow;

note: rainfall-runoff number of events corresponds to the number from Table 4; source: own study

For the studied events, we have noticed that the grassland exerts a strong and similar retention effect on the water flow pathways in time spread, peak plothydrographs of $H O F$, and runoff coefficients (Fig. 3). In fact, in extreme dry conditions a rain of $16.8 \mathrm{~mm}$ depth or more could be totally retained in the soil. Otherwise, the most visible discharge element, peak discharge, was for the $H O F$ grassland in most cases attenuated and lagged (see example Fig. 3a, b). Thus, we consider that for these conditions, rainfall events with a layer less than $16 \mathrm{~mm}$ can certainly improve the hydric soil deficiency and the hydric stress of the grass. Under low drought conditions (wet), grassland capacity for interception, retention, and drain coefficients, decreases, and volumes for $H O F$ were higher than bare soil (see Fig. 3c, d).

However, we can say that the grass effect manifest as diminishing peak discharges, and even more; the infiltration has prompted that $D P$ discharge to be dominant in both land use types. In general, by observing the quasi-total retention of rain, especially for $H O F$, from the point of view of the formation of water resources, in extreme dry conditions, it was possible to ascertain the negative effect of the secondary grasslands in the dry conditions in the suppression of water resources on hillslopes.

2. As regards the hydrological attenuation capacity of $H O F$ over the successive rainfall events, from the data analysed, it is reasonable to assume that successive rainfall events can generate a runoff, but we have thoroughly found the following: (i) grass can reduce $H O F$ during events up to $90 \%$ as compared to bare soil (e.g., see 14 event from Fig. 4); (ii) the length and intensity of rainfall events is a key factor (see Figure 3 c, d; Fig. 4). Certainly, it was observed that after a dry period (September 2016), 3 storm events contributed to the restoration of moisture content, and secondary grassland had high potential of precipitation redistribution, to regulate the runoff in $H O F$ (minor runoff, strong $Q_{\max }$ and reduced runoff coefficients; see Fig. 4). The particularity of the secondary grassland influence on the runoff is noted at the $S S F$ level, where the most important volumes are specific on the grassland. In contrast, the $D P$ response was substantial - preferential flow (see 15 rainfallrunoff event from Fig. 4).

In addition, we need to strongly assess the relationship between rainfall events, storm events in particular, under dry conditions, with respect to water flow pathways. In the present work, we found that the rainfall-runoff response did not help to adequately explain and predict the water flow pathways process. Further work is necessary to improve rainfall-runoff data sets (more storm events to study, more sprinkler experiments) that cover all periods with vegetation phenology in extreme dry conditions.

\section{CONCLUSIONS}

In this research, we aimed to investigate how secondary grassland can affect the runoff generation in drought conditions on hillslopes at plot-scale. The runoff generation on flow pathways (Hortonian overland flow $(H O F)$, subsurface flow $(S S F)$ or interflow and deep percolation $(D P)$ ) in drought conditions after heavy rainfalls turned out to be a complex process. 
The runoff generation process and the identification of the water flow pathways on hillslopes during drought are not easily explained. Our investigation revealed that the differing runoff coefficients and water flow pathways (like $H O F$ ) of land use (grasslands vs. bare soil) under given drought conditions in relation to natural rainfall events can be better understood by carrying out some extended experiments.

In temperate continental climate, we found that runoff processes on secondary grassland hillslopes under drought conditions are governed by high infiltration and, secondly soil storage. Also, hydrologic differences in runoff formation on different land use types (grasslands vs. bare soil) were observed.

Importantly, in extreme drought conditions, only rainfalls of $31 \mathrm{~mm}$ have ability to produce runoff $(H O F)$, and decreases to $17 \mathrm{~mm}$ for moderate drought and to $8 \mathrm{~mm}$ for wet conditions. These thresholds were conditioned by the duration and intensity of precipitation. From 208 rainfall events that have occurred with different depths and intensities, only 16 of them (7.7\%) generated runoff.

The results showed that rainfall events of low intensity infiltrate into the soil. Rainfall event characteristics was followed in importance by the type of land use, which was highly responsive to minor runoff events in drought conditions.

The rainfall events up to $16 \mathrm{~mm}$ were insufficient to completely saturate the soil. Therefore, we observed a minor contribution of $H O F$ on grassland and a slight one on bare soil. In severe drought conditions, slightly larger volumes of $H O F$ and $D P$ were drained on bare soil. Soil-water deficiencies limited water flow pathways, especially for SSF.

On bare soil, important water volumes were accumulated in matrix and macropores, followed by delayed gravity drainage to the base flow.

Grasslands affected the water flow pathway, $H O F$ in particular. Grasslands have reduced the discharge peak and most of the water volumes, comparatively with bare soil conditions. These circumstances can be explained by interception and retention followed by water absorption in the root layer and soil water storage. A complementary and negative effect of grasslands in drought conditions is the suppression of water resources on hillslopes.

The obtained results allowed a preliminary identification of water flow pathways by showing the dominant runoff processes and the influence of temperate grasslands on runoff process on hillslopes. Answers to some key questions remain open regarding the hydrological interaction between grasslands and soil in drought conditions, such as if a linear relationship between rainfall and runoff exists for the grassland and if this relationship can be used to predict water flow pathways.

However, in order to reach a good understanding of hydrologic grasslands effects at plot-scales, further analyses extended to large data sets from growing seasons are needed.

\section{ACKNOWLEDGMENTS}

Gabriel Minea is grateful to the Research Institute of the University of Bucharest (ICUB, see logo), for the support to carry out (postdoctoral research) the present work. A great part of this work was performed at the National Institute of Hydrology and Water Management.

We thank prof. univ. dr. Carmen Chifiriuc, coordinator of ICUB, for methodological and linguistic support and to our anonymous referees for their comments on the first version of this paper draft. Moreover, we would like to thank the Voinești Experimental Basin field specialists (in particular to hidr. George Niţă and Cătălin Barbu) who were involved in data collection.

We would like to thank the three anonymous reviewers for their helpful and constructive comments that assisted in improving this manuscript. Editing and proofreading by PhD student Gabriela Adina Moroșanu streamlined the flow and message of this manuscript.

\section{REFERENCES}

Abrantes J.R.C.B., De Lima J.L.M.P., Prats S.A., Keizer J.J. 2017. Assessing soil water repellency spatial variability using a thermographic technique: An exploratory study using a small-scale laboratory soil flume. Geoderma. Vol. 287 p. $98-104$.

BĄK B., KUBIAK-WÓJCICKA K. 2017. Impact of meteorological drought on hydrological drought in Torun (central Poland) in the period of 1971-2015. Journal of Water and Land Development. No. 32 p. 3-12. DOI 10.1515/ jwld-2017-0001.

BLIDARU S. 1965. Emploi des bassins représentatifs et des stations expérimentales a l'étude des phénomènes hydrologiques. In: Bassins représentatifs et expérimentaux [Characteristic basins and experimental stations used in the determination of hydrological phenomena. In: Representative and experimental areas]. Symposium of Budapest. Vol. 2. Publ. No. 66 p. 107-115.

BlÖSCHL G., SivaPAlan M. 1995. Scale issues in hydrological modelling: a review. Hydrological Processes. Vol. 9. Iss. 3-4 p. 251-290.

Brocca L., Melone F., Moramarco T. 2008. Soil moisture monitoring at different scales for rainfall-runoff modelling [online]. International Congress on Environmental Modelling and Software. No. 63 p. 407-414. [Access 31.08.2017]. Available at: http:// scholarsarchive.byu.edu/iemssconference/2008/all/63

Cerda A., Rodrigo-Comino J., Novara A., Brevik E.C., VAez A.R., Pulido M., Giménez-Morera A., KeEsSTRA S.D. 2018. Long-term impact of rainfed agricultural land abandonment on soil erosion in the Western Mediterranean basin. Progress in Physical Geography. Vol. 42. Iss. 2 p. 202-219. DOI 10.1177/030913331875 8521.

DAI A. 2013. Increasing drought under global warming in observations and models. Nature Climate Change. Vol. 3. Iss. 1 p. $52-58$.

DE LIMA J.L.M.P., SingH V.P. 2002. The influence of the pattern of moving rainstorms on overland flow. Advances in Water Resources. Vol. 25 p. 817-828.

Delta-T 2016. User manual for the profile probe type PR2. PR2-UM-5.0. Cambridge. Delta-T Devices Ltd. pp. 48. 
Duan J., Yang J., Tang C., Chen L., Liu Y., Wang L. 2017. Effects of rainfall patterns and land cover on the subsurface flow generation of sloping Ferralsols in southern China. PloS One. Vol. 12. Iss. 8 e 0182706.

FULLEN M.A. 1992. Erosion rates on bare loamy sand soils in east Shropshire, UK. Soil Use and Management. Vol. 8. Iss. 4 p. $157-162$.

FULLEN M.A. 1998. Effects of grass ley set-aside on runoff, erosion and organic matter levels in sandy soils in east Shropshire, UK. Soil and Tillage Research. Vol. 46. Iss. 1-2 p. 41-49.

Gholami L., Banasik K., Sadeghi S.H., Khaledi DarviSHAN A., HEJDUK L. 2014. Effectiveness of straw mulch on infiltration, splash erosion, runoff and sediment in laboratory conditions. Journal of Water and Land Development. No. 22 p. 51-60.

Holko L., LePISTÖ A. 1997. Modelling the hydrological behaviour of a mountain catchment using TOPMODEL. Journal of Hydrology. Vol. 196. Iss. 1 p. 361-377.

HORTON R.E. 1919. Rainfall interception. Monthly Weather Review. Vol. 47. Iss. 9 p. 603-623.

Hottenstein J. D., Ponce-Campos G. E., Moguel-Yanes J., MORAN M.S. 2015. Impact of varying storm intensity and consecutive dry days on grassland soil moisture. Journal of Hydrometeorology. Vol. 16. Iss. 1 p. 106117.

IONIȚĂ I., RĂDOANE M., MiRCEA S. 2006. Romania. In: Soil erosion in Europe. Eds. J. Boardman, J. Poesen. John Wiley \& Sons, Ltd. p. 155-166.

JANKOWSKA-HUFLEJT H. 2006. The function of permanent grasslands in water resources protection. Journal of Water and Land Development. No. 10 p. 55-65.

Joyce C. B., Simpson M., CASAnOva M. 2016. Future wet grasslands: ecological implications of climate change. Ecosystem Health and Sustainability Vol. 2. Iss. 9: e01240. DOI 10.1002/ehs2.1240.

Khezazna A., Amarchi H., Derdous O., Bousakhria F. 2017. Drought monitoring in the Seybouse basin (Algeria) over the last decades. Journal of Water and Land Development. No. 33 p. 79-88. DOI 10.1515/jwld20170022.

Latron J., Anderton S., White S., Llorens P., Gallart F. 2003. Seasonal characteristics of the hydrological response in a Mediterranean mountain research catchment (Vallcebre, Catalan Pyrenees): Field investigations and modelling. International Association of Hydrological Sciences Publication. No. 278 p. 106-110.

Macleod C.J.A, Humphreys M.W., Whalley W.R., Turner L, Binley A, WATTS C.W., SKøT L., JOYNES A., HaWkins S., King I.P., O'DONOVAN S., HAYGARTH P.M. 2013. A novel grass hybrid to reduce flood generation in temperate regions. Scientific Report. No. 3. Art. No. 1683.

Macleod C.J.A., Binley A., Hawkins S. L., Humphreys M. W., Turner L.B., Whalley W. R., Haygarth P. M. 2007. Genetically modified hydrographs: what can grass genetics do for temperate catchment hydrology? Hydrological Processes. Vol. 21. Iss. 16 p. 2217-2221.

Maetens W., Vanmaercke M., Poesen J., Jankauskas B., JANKAUSKIENE G., IONIȚĂ I. 2012. Effects of land use on annual runoff and soil loss in Europe and the Mediterranean: A meta-analysis of plot data. Progress in Physical Geography. Vol. 36. Iss. 5 p. 599-653.

Maftei C., Chevallier P., Ciurea C., Roșu L. 2002. Considerations concerning the characteristics of permeability of the podzolic soil in Voinesti catchment. "Ovidius"
University Annals Constantza. Series Civil Engineering. Vol. 1. Iss. 3/4 p. 525-530.

Marzen M., Iserloh T., Casper M.C., Ries J.B. 2015. Quantification of particle detachment by rain splash and wind-driven rain splash. Catena. Vol. 127 p. 135-141.

Minea G., Adler M. J., Moroșanu G., Neculau G. 2015. The relationship between flow rates and land use at plot scale in the Voineşti Experimental Basin (Romania). Scientific Papers. Ser. E. Land Reclamation, Earth Observation and Surveying, Environmental Engineering. Vol. 4 p. 88-94.

Minea G., Iliescu M., Dedu F. 2016. Temporal rainfall properties at events scale in the Curvature Subcarpathians (Romania). In: Forum Geographic. Eds.G. Minea, G. Neculau, J.L.M.P. de Lima. Vol. 15. Suppl. 2 p. 115 123.

Minea G., Moroşanu G.A. 2016. Micro-scale hydrological field experiments in Romania. Open Geosciences. Vol. 8. Iss. 1 p. 154-160.

Mircea S., Petrescu N., Tronac A. 2015. Some aspects concerning gully erosion process in small torrential watersheds and its impact on environment. Carpathian Journal of Earth and Environmental Sciences. Vol. 10. Iss. 2 p. $115-122$.

MițĂ P., MătreațĂ. S. 2016. Representative basins in Romania: Synthesis of research result. Bucharest. Didactica Publishing House. ISBN 9786063102967 pp. 36.

OriginLab Corp. 2016. Origin Pro 2016. Version b9.3.2.303. Northampton, MA, U.S.A.

OudA S.A., NORELdin T., MOUNZER O.H., ABDELhAMid M.T. 2015. CropSyst model for wheat irrigation water management with fresh and poor quality water. Journal of Water and Land Development. No. 27 p. 41-50. DOI 10.1515/jwld-2015-0023.

Peel M.C., Finlayson B. L., Mcmahon T.A. 2007. Updated world map of the Köppen-Geiger climate classification. Hydrology and Earth System Sciences Discussions. Vol. 4. Iss. 2 p. 439-473.

Rodríguez-Blanco M.L., TABOADA-CAStro M.M., TABOADA-CASTRO M.T. 2012. Rainfall-runoff response and event-based runoff coefficients in a humid area (Northwest Spain). Hydrological Sciences Journal. Vol. 57. Iss. 3 p. $445-459$.

ScherRer S., NAEF F., FAeH A. O., CORdery I. 2007. Formation of runoff at the hillslope scale during intense precipitation. Hydrology and Earth System Sciences Discussions. Vol. 11. Iss. 2 p. 907-922.

Schmocker-Fackel, P., Naef, F., Scherrer, S. 2007. Identifying runoff processes on the plot and catchment scale. Hydrol. Earth Syst. Sci. Discuss., Iss. 3 p. $2063-$ 2100.

SPEI 2017. Global drought monitor [online]. The Global SPEI. [Access 30.09.2017]. Available at: http://spei. csic.es/map

Stan F., Neculau G., Zaharia L., Ioana-Toroimac G. 2014. Evapotranspiration variability of different plant types at Romanian experimental evapometric measurement stations. Climatologie. Vol. 11 p. 85-90.

StANCIU P., Zlate-PoDANI I. 1987. A study of hydrological regimes in experimental basins in relation to cultivation practices. In: Water for the future: Hydrology in perspective. Eds. J.C. Rodda, N.C. Matalas. IAHS Publication. No. 164 p. $193-203$.

VAN LOON A.F. 2015. Hydrological drought explained. Wiley Interdisciplinary Reviews: Water. Vol. 2. Iss. 4 p. 359-392. 
Vicente-SERrano S.M., Beguería S., LÓPEZ-Moreno J.I. 2010. A multiscalar drought index sensitive to global warming: The standardized precipitation evapotranspiration index. Journal of Climate. Vol. 23. Iss. 7 p. $1696-$ 1718.

Vicente-SERrano S.M., LÓPEZ-MORENO J.I., BEGUería S., Lorenzo-Lacruz J., Azorin-Molina C., MorÁn-TeJeDA E. 2011. Accurate computation of a streamflow drought index. Journal of Hydrologic Engineering. Vol. 17(2) p. 318-332.
Warwade P., Tiwari S., Ranjan S., Chandniha S.K., ADAMOWSKI J. 2018. Spatio-temporal variation of rainfall over Bihar State, India. Journal of Water and Land Development. No. 36 p. 183-197. DOI 10.2478/ jwld2018-0018.

ZAHARIA L., IOANA-TOROIMAC G. 2009. Erosion dynamics precipitation relationship in the Carpathian's Curvature Region (Romania). Geografia Fisica e Dinamica Quaternaria. Vol. 32 p. 95-102.

\section{Gabriel MINEA, Georgiana TUDOR, Florentina-Iuliana STAN, Gabriela IOANA-TOROIMAC, Raluca ZAMFIR}

\section{W jaki sposób użytki zielone w okresie opadów mogą modyfikować bilans wodny w warunkach suszy}

\section{STRESZCZENIE}

Biorąc pod uwagę dobrze znany wpływ użytków zielonych na stokach na odpływ wody, celem było zbadanie, jak te siedliska mogą wpływać na drogi przepływu wody w warunkach suszy. Badania prowadzono na eksperymentalnych poletkach porośniętych na przykład przez Festuca pratensis w warunkach umiarkowanie wilgotnego klimatu kontynentalnego na Pogórzu Karpackim w Rumunii. Do analizy użyto dane o opadach, ewapotranspiracji i wilgotności gleby (208 danych o opadach i 16 kombinacji opad-odpływ) pozyskanych z pomiarów na pagórkach pokrytych roślinnością trawiastą w sezonie wegetacyjnym od 1 kwietnia do 30 września w latach 2015 i 2016. Uzyskane wyniki wskazują, że odpływ w warunkach skrajnej suszy występuje w siedliskach trawiastych jedynie wtedy, gdy opad przekroczy wartość $31 \mathrm{~mm}$ powierzchniowego odpływu Hortona $(H O F)$. Wartość $H O F$ maleje do $17 \mathrm{~mm}$ w warunkach umiarkowanej suszy i do $8 \mathrm{~mm}$ w warunkach wilgotnych. Okresy opadów do $16 \mathrm{~mm}$ okazały się niewystarczające do całkowitego nasycenia gleby. Z tego powodu przepływ powierzchniowy ma w warunkach suszy znikome znaczenie w siedliskach trawiastych i niewielkie na odkrytej glebie. Komplementarnym i ujemnym skutkiem występowania użytków zielonych jest ograniczenie zasobów wodnych na stokach.

Słowa kluczowe: drogi przepływu wody, poletka badawcze, susza hydrologiczna, użytki zielone, zdarzenia opad-odptyw 